\title{
Kewenangan Notaris/PPAT \\ dalam Menerima Penitipan Pembayaran Pajak Bea Perolehan Hak Atas Tanah dan Bangunan
}

\author{
Riyan Hidayat ${ }^{1}$
}

${ }^{1}$ PT. Nindya Karya (Persero) Wilayah IV, Kota Denpasar Provinsi Bali-Indonesia,

E-mail: riyan.hidayat@nindyakarya.co.id

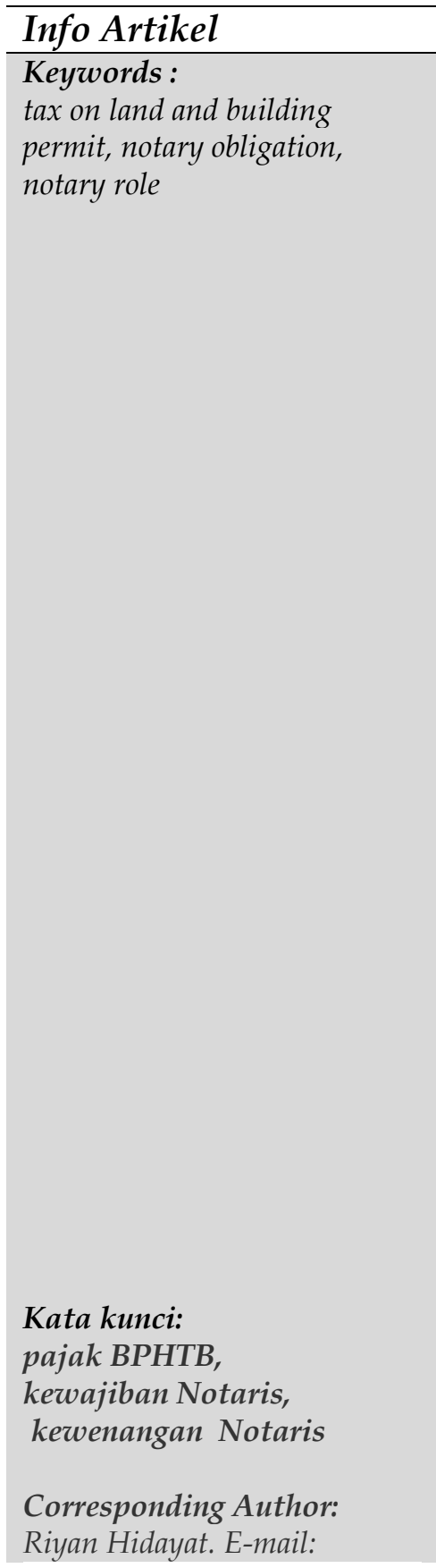

\begin{abstract}
One of the potential sources of tax revenues that should be explored in accordance with the current economic situation and the development of the nation's development is the type of tax on land and building use permit in after abbreviated as BPHTB. In managing the Tax on land and building permit, the eligible party is the central government, but the acceptance of tax on land and building permit is largely as an income for the region. Depositing tax on land and building permit is the obligation of the taxpayer, but in fact many tax payers deposit the payment to notary / the official certifier of title deeds whereas in the authority of notary which is regulated in the amendment of law on notary, there is no one article that determines notary obligation for paying care work tax on land and building permit. The problems of this study are how the role of Notary / the official certifier of title deeds in the tax payments on land is and building use permit and how the responsibility Notary / the official certifier of title deeds in relation to the payment of on land is and building use permit's sale and purchase. The empirical juridical legal research method is applied in this study. This study belongs to descriptive analysis by analyzing primary data and applying interview techniques for the primary data and literature review technique for the secondary data. The techniques of qualitative method are examining, analyzing, interpreting and drawing conclusion from literature review. The result of the study shows that for notary who receives the deposit payment of tax on land and building permit shall be an action undertaken to assist and facilitate the transaction process and notary public as a public officer deemed to have a better understanding of the tax payment procedure should properly assist in the execution of the tax payment but it is not entitled to charge fees for the deposit because it is not a notary's task which only acts on the basis of her/himself.
\end{abstract}

\section{Abstrak}

Salah satu sumber potensi prolehan pajak yang perlu digali sesuai situasi dan kondisi perekonomian serta perkembangan pembangunan bangsa sekarang ini adalah jenis Pajak Bea Perolehan Hak Atas Tanah dan Bangunan selanjutnya disingkat BPHTB. Dalam mengelola BРНTB yang berhak adalah pemerintah pusat, namun penerimaan BPHTB sebagian besar merupakan pemasukan bagi daerah. Penyetoran BРНTB 


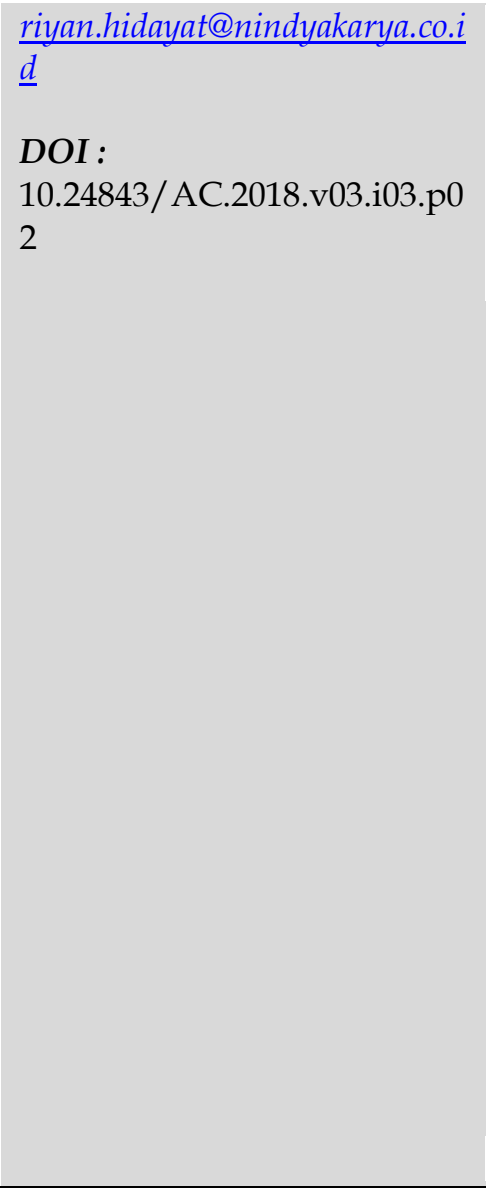

merupakan kewajiban wajib pajak, namun pada kenyataanya banyak wajib pajak yang menitipkan pembayarannya kepada Notaris/PPAT padahal dalam kewenangan Notari yang diatur dalam UUJN tidak ada satupun pasal yang menentukan kewajiban Notaris untuk pekerjaan penitipan pembayaran BPHTB.Permasalahan yang dapat diangkat dalam penelitian ini adalah Bagaimana kewenangan Notaris/PPAT dalam penitipan pembayaran pajak BPHTB dan bagaimana tanggung jawab Notaris/PPAT dalam kaitannya dengan pembayaran BPHTB atas jual beli tanah dan bangunan.Penelitian ini menggunakan metode penelitian hukum yuridis empiris. Sifat penelitian deskriptif analisis dengan teknik pengumpulan data primer dengan teknik wawancara dan teknik pengumpulan data sekunder dengan cara telaah kepustakaan. Teknik analisis data dengan metode kualitatif yaitu dianalisis dengan cara mempelajari, menganalisis, menafsirkan dan menarik kesimpulan dari studi kepustakaan dan fenomena yang ada di lapangan kemudian ditarik kesimpulan Hasil peneilitian ini menunjukan bahwa Notaris yang menerima penitipan atas pembayaran ВРНТВ merupakan suatu tindakan yang dilakukan untuk membantu dan memperlancar proses transaksi dan Notaris sebagai pejabat umum yang dianggap lebih memahami prosedur pembayaran pajak tersebut maka sudah sepantasnya membantu dalam melaksanakan pembayaran pajak namun tidak berhak untuk memungut biaya atas penitipa tersebut karena hal itu bukan menjadi pekerjaan Notaris hanya saja bertindak atas dasar diri pribadi.

\section{Pendahuluan}

Pajak merupakan salah satu pendapatan terbesar oleh Negara maupun oleh daerah. Pajak daerah merupakan salahsatu kontribusi wajib oleh wajib pajak untuk daerah yang dikenakan kepaada orang pribadi atau badan yang bersifat memaksa namun wajib pajak tidak mendapat imbalan secara langsung atas pajak yang dibayarkannya. Salah satu bentuk pajak yang harus disetor kepada pemerintah daerah yaitu pajak Bea Perolehan Hak Atas Tanah dan Bangunan. Pajak BPHTB merupakan pajak yang awalnya menjadi kewenangan pemerintah pusat namun setelah adanya UndangUndang Nomor 28 Tahun 2009 tentang Pajak Daerah Dan Retribusi maka pajak BPHTB menjadi kewenangan daerah untuk memungutnya.

Pada dasarnya semua pajak yang diberlakukan di Indonesia harus berdasarkan undang-undang, sehingga pemungutan pajak mempunyai dasar hukum yang menjamin keadilan dan kepastian hukumnya. Pajak merupaka iuran wajib kepada Negara yang dapat dipaksakan dan terhutang oleh yang wajib membayarnya menurut peraturan perundang-undangan yang berlaku dengan tidak mendapat prestasi kembali secara langsung, yang sebagian besar digunakan untuk membiayai pengeluaran umum yang berhubungan dengan tugas Negara untuk penyelenggaraan pemerintahan. ${ }^{1}$

${ }^{1}$ Marihot Pahala Siahaan, Hukum Pajak Elementer Konsep Dasar Perpajakan Indonesia, Edisi I, Cet. I (Yogyakarta : Graha Ilmu, 2010), h. 32. 
Seiring perkembangan ekonomi, pajak telah menjadi salah satu primadona untuk pemerintah karena memberikan penerimaan yang cukup besar bagi Negara serta sebagai salah satu dana utama dalam melakukan pembangunan. Pajak BPHTB merupakan salah satu sumber pendapatan terbesar daerah. Pajak Bea Perolehan Hak Atas Tanah dan Bangunan merupakan pajak yang dikenakan atas perolehan hak atas tanah dan/atau bangunan. Menurut B Ilyas bahwa pajak BPHTB merupakan perolehan hak atas tanah dan bangunan yang dapat berupa tanah dan bangunan. ${ }^{2}$.

Pajak BPHTB timbul karena adanya suatu proses transaksi peralihan hak atas tanah maupun bangunan yang dilakukan oleh orang ataupun badan yang kemudian dibuatkan akta dihadapat Notaris/PPAT yang berwenang untuk membuat akta autentik dan kemudian didaftarkan pada Badan Pertanahan Setempat. Berdasarkan ketentuan dalam pasal 1 Undang-undang Nomor 2 Tahun 2014 perubahan atas Undang-Undang Nomor 30 Tahun 2004 tentang Jabatan Notaris (selanjutnya disebut UUJN). Notaris merupakan pejabat umum yang memiliki kewenangan untuk membuat akta autentik serta kewenanganlainnya sebagaimana yang dimaksud dalam undang-undang jabatan Notaris. Notaris dalam menjalankan tugas nya harus memberikan penjelasan kepada klien mengenai akta yang akan dibuat oleh para pihak atau misalnya dalam pembayaran pajak BPHTB dan proses dan syarat-syarat yang harus dipersiapkan.

Pembayaran pajak BPHTB tersebut merupakan kewenangan bagi para wajib pajak, bukan Notaris. Namun pada kenyataanya banyak klien yang menitipkan pembayaran dan Notaris pun menerima penitipan tersebut namun biasanya atas nama diri pribadi. Notaris sebagai pejabat secara tidak langsung memberikan kemudahan bagi para wajib pajak untuk dapat menyetorkan pajaknya dengan mudah.

Pada UUJN tidak terdapat pasal yang mengatur mengenai kewenangan Notaris sebagai pejabat umum untuk menyetorkan pajak BPHTB. Dalam UUJN yang menjadi kewenangan Notaris adalah antara lain:

1. Notaris berwenang untuk membuat akta autentik mengenai semua perbuatan, perjanjian dan ketetapan yang diharuskan oleh peraturan perundangundangan dan atau yangdikehendaki oleh orang yang berkepentingan untuk dinyatakan dalamakta autentik tersebut; menjamin kepastian tanggal pembuatan akta, menyimpan akta, memberikan grose, salinan dan kutipan akta, semuanya itu sepanjang pembuat akta itu tidak jua ditugaskan atau dikecualikan kepada pejabat lain atau orang lain yang ditetapkan oleh undangundang.

2. Berdasarkan pasal 15 UUJN, Notaris juga berwenang:

1) Mengesahkan tandatangan dan menetapkan kepastian tanggal surat dibawah tangan dengan mendaftar dalam bukum khususs.

2) Membukukan surat di bawah tangan dengan mendaftar dalam buku khusus.

3) Membuat kopi dariasli surat di bawah tangan berupa salinan yang memuat uraian sebagaimana ditulis dan digambarkan dalam surat yang bersangkutann.

\footnotetext{
2 Wirawan B.Ilyas, Richard Burton, Hukum Pajak, Edisi Revisi, Salemba Empat, Jakarta, 2004, h.90
} 
4) Melakukan pengesahan kecocokan dan fotokopi dengan surat asli.

5) Memberikan penyuluhan hukum sehubungan dengan perbuatan akta.

6) Membuat akta yang berkaitan dengan pertanahan.

7) Membuat akta risalah lelang.

Dalam melaksanakan jabatannya, Notaris diwajibkan untuk selalu berpedoman pada UUJN dan Kode Etik Profesi. Kode Etik dipahami sebagai norma dan peraturan mengenai etika baik yang tertulis maupun tidak tertulis dari suatu profesi yang fungsinya sebagai pengingat berprilaku bagi para anggota organisasi profesi. ${ }^{3}$ Seorang Notaris dalam melakukan jabatannya harus penuh tanggungjawab dengan tetap menjaga norma , etika, kesusilaan, ketertiban umum serta mampu berbahasa Indonesia dengan baik. 4

Sebagai pejabat umum, tugas utama Notaris yaitu melayani masyarakat dengan harapan mampu memberikan sumbangan bagi pembangunan hukum nasional. Sehingga dalam membantu masyarakat seorangg Notaris harus memiliki moral yang tinggi. Moralitas pejabat akan tercapai jika kita mentaati hukm dan takut pada Tuhan namun harus bersumber dari diri kita sendiri dan harus menyadari bahwa itu merupakan kewajiban sebagai seorang profesi Notaris. Frans mengemukakan lima kriteria moral yang mendasari kepribadian profesional hukum yaitu sebagai berikut:

1. Kejujuran, tanpa adanya kejujuran maka professional hukummengingkari misi profesinya. Seorang Notaris harus jujur dalam melaksanakan tugas dankewajibannya.

2. Autentik, yaitu menunjukkan diri sesuai dengan keasliannya dan tidak melakukan perbuatan merendahkan martabat profesi.

3. Bertanggung jawab, Seorang Notaris harus bertanggung jawab dalam melaksanakan tugasnya, bertindak secara professional tanpa membedakan perkara pembayaran dan perkara Cuma-Cuma

4. Kemandirian moral, yaitu tidak mudah terpengaruh dengan hasutan orang lain

5. Keberanian moral, artinya kesediaan terhadap suatu hati nurani yang menyatakan kesediannya untuk menanggung resiko konflik. ${ }^{5}$

Seorang Pejabat Umum dalam hal ini Notaris selaku PPAT dalam melakukan profesinya sebagai pembuat akta autentik, berhubungan erat dengan perpajakan. Notaris sebagai pejabat yang mengetahui tentang maslah perpajakan sudah seharusnya memberikan informasi tentag pembayaran BPHTB, Berdasarkan uraian diatas maka dapat dirumuskan dua permasalahan sebagai berikut:

1. Bagaimanakah kewenangan Notaris/ PPAT dalam penitipan pembayaran pajak BPHTB?

2. Bagaimana tanggung jawab Notaris/PPAT dalam kaitannya dengan pembayaran BPHTB atas jual beli tanah dan bangunan?

\footnotetext{
${ }^{3}$ Ikatan Notaris Indonesia, Jati Diri Notaris Indonesia, Dulu, Sekarang dan Di Masa Datang, Jakarta, PT. Gramedia, 2008, h. 93-94

${ }^{4}$ C.S.T. Kansil, S.H \& Chistine S.T Kansil, S.H., M.H, Pokok-Pokok Etika Profesi Hukum, PT.Pradnya Paramita, Jakarta, 1996, h.87

${ }^{5}$ S.P. Lili Tjahjadi, Hukum Moral, Kanisius, Yogyakarta, 1991, h.47
} 
Dalam penulisan karya ilmiah maka diperlukan suatu teori untuk melandasi akan hasil dari penelitian. Teori merupakan seperangkat proposisi yang abstrak dan antara variable yang satu dengan yang lainnya saling berhubungan sehingga menghasilkan pandangan yang yang sistematis. ${ }^{6}$ Sedangkan teori berfungsi untuk mensistimatisasi penemuan-penemuan penelitian, membuat prediksi dan menyajikan penjelasan yang dalam hal ini untuk menjawab pertanyaan pada rumusan masalah. ${ }^{7}$

Kelsen menyatakan bahwa suatu yang memiliki hubungan dengan konsep kewajiban hukum adalah konsep tanggung jawab hukum. Seseorang bertanggung jawab secara hukum atas suatu perbuatannya atau dia memikul tanggungjawab hukum. Hal ini berarti seseorang harus bertanggung jawab atas suatu sanksi dalam hal perbuatan yang bertentangan. Biasanya yakni dalam hal sanksi ditujukan kepada parapelaku langsung, seorang bertanggung jawab atas perbuatannya. ${ }^{8}$

Seorang dikatakan bertanggung jawab secara hukum apabila seseorang tersebut dapat dikenakan sanksi dalam kasus perbuatan yang berlawanan. Teori tanggungjawab hukum diperlukan untuk dapat menjelasksan antara tanggung jawab Notaris yang berkaitan dengan kewenangan Notaris berdasarkan UUJN. Pembayaran pajak BPHTB itu merupakan kewenangan dari si wajib pajak bukan Notaris, namun dalam hal ini Notaris dapat menyetorkan pajak BPHTB apabila nasabahnya menitipkan uang untuk pembayaran BPHTB tersebut kepada Notaris. Jadi, Notaris disini sebagai orang yang dipercaya oleh nasabahnya untuk menyetorkan pajak BPHTB. Jadi dalam hal ini penyetoran pajak BPHTB bukan merupakan kewenangan daripada Notaris melainkan kewenangan dari wajib pajak itu sendiri.

Keberadaan Notaris senantiasa diperlukan masyarakat yang memerlukan jasanya di bidang hukum. Notaris sebagai pejabat umum sudah seharusnya mengikuti akan kemajuan perkembangan hukum sehingga dalam memberikan jasanya Notaris harus dapat membantu masyarakat Pembayaran BPHTB yang dititipkan oleh wajib pajak kepada Notaris untuk disetor dan tidak disetorkan oleh Notaris maka perbuatan yang dilakukan oleh Notaris tersebut dapat dikatakan telah melanggar kode etik profesi dan tindak pidana penggelapan pajak BPHTB. Notaris tersebut dalam melaksanakan tugas dan tanggungjawabnya tidak berdasarkanatas UUJN dank ode etik profesi Notaris.

Dalam menjalankan profesinya, notarsi harus memperhatikan unsur-unsur prilaku seorang profesi yaitu:

1. Berintegritas moral yang baik.

2. Jujur terhadap klien dan diri sendiri

3. Sadar terhadap batas kewenangan

4. Tidak mengutamakan uang 9

Tugas profesi Notaris tidak hanya berhubungan dengan standar profesi dan etika profesi yang keduanya merupakan petunjuk umum saja, melainkan hubungan positif

${ }^{6}$ Maria S.W. Sumardjono, 1989, Pedoman, Pembuatan Usulan Penelitian, Gramedia, Yogyakarta, h. 12

7M. Solly Lubis (I), 1994, Filsafat Ilmu dan Penelitian, Mandar Maju, Bandung, h. 80.

${ }^{8}$ Hans Kelsen, Teori Hukum Murni dengan judul buku asli General Theori of Law and State, Alih Bahasa Somardi, Rimdi Press, Jakarta, h.65

${ }^{9}$ Liliana Tedjosaputra, 2003, Etika Profesi dan Profesi Hukum, Aneka Ilmu, Semarang, h.93.

${ }^{9}$ E.Y. Kanter, 2001, Etika Profesi Hukum, Storia Grafika, Jakarta, h. 19. 
akan berkesempatan besar untuk tampil mengambil alih perannya gunamencegah terjadinya penyimpangan dari tugas profesinya. ${ }^{10}$

Profesi dan etika merupakan suatu hal yang tidak bisa dipisahkan. Untuk menjadi seorang profesional harus memiliki etika yang baik. Dalam pasal 4 ayat 2 UUJN menyatakan bahwa Notaris akan menjaga sikap, tingkah laku dan akan menjalankan kewajiban sesuai dengan kode etik profesi, kehormatan, martabat dan tanggungjawab sebagai Notaris. ${ }^{11}$ Berarti bahwa Notaris dalam menlajalankan tugas dan kewajiban wajib menjunjung tinggi harkat dan martabat profesinya itu karena menyangkut kewibawaan pemerintah, disamping itu juga martabat secara pribadi yaitu moral Notaris itu sendiri dalam kehidupan pribadinya.

Menurut konsep teori kewenangan Philipus M. Hadjon bahwa setiap tindakan pemerintahan disyaratkan harus bertumpu atas kewenangan yang sah. Kewenangan itu diperoleh melalui tiga sumber yaitu atribusi, delegasi dan mandat. Kewenangan atribusi lazimnya digariskan melalui pembagian kekuasaan negara oleh undangundang, kewenangan delegasi adalah kewenangan yang berasal dari adanya pelimpahan kewenangan secara atributif sedangkan mandat tidak terjadi suatu pelimpahan kewenangan. ${ }^{12}$

Dalam kaitannya dengan penelitian ini bahwa teori kewenangan ini digunakan untuk membahas dan menganalisis masalah tentang kewenangan Notaris dalam menerima penitipan pembayaran pajak terkait dengan akta autentik yang dibuatnya. Dengan mengetahui wewenangnya maka akan dapat memberi kejelasan terhadap boleh atau tidaknya seorang Notaris/PPAT untuk menerima penitipan pembayaran pajak BPHTB baik atas nama diri sendiri maupun atas nama jabatannya.

Adapun tujuan penelitian antara lain yaitu untuk mengetahui dan memahami bagaimana peran Notaris/PPAT dalam kaitannya dengan pembayaran BPHTB atas jual beli tanah dan bangunan dan untuk menambah wawasan untuk penulis agar mengetahui bagaimana tanggung jawab Notaris/PPAT dalam penitipan pembayaran pajak BPHTB

\section{Metode Penelitian}

Metode penelitian dapat diartikan sebagai proses prinsip-prinsip dan tata cara untuk memecahkan suatu permasalahan dalam suatu penelitian.

\subsection{Jenis Penelitian}

Sui Generis dalam peristilahan hukum adalah ilmu jenis sendiri dalam hal cara kerja dan sistem ilmiah. Penelitian ini sesuai dengan karakter "sui generis" dari ilmu hukum oleh karena itu penelitian ini difokuskan terhadap bahan-bahan hukum yang berkaitan

11 Hadi Setia Tunggal, 2006, Peraturan Pelaksanaan Undang-Undang Jabatan Notaris dilengkapi Putusan Mahkamah Konstitusi \& AD, ART, dan Kode Etik Notaris, Harvarindo, Jakarta, hal.36

12 I Gusti Agung Dhenita Sari, 2017, Kewenangan Notaris Dan PPAT Dalam Proses Pemberian Hak Guna Bangunan Atas Tanah Hak Milik, Acta Comitas, Universitas Udayana. 
dengan pokok-pokok permasalahan. Bahan hukum yang dipergunakan guna penyusunan dan pembahasan permasalahan dalam penelitian ini digunakan metode Penelitian Hukum Normatif yakni beranjak dari adanya kekosongan norma hukum atau asas hukum dalam hal kewenangan Notaris/PPAT dalam menerima penitipan pembayaran pajak BPHTB.

\subsection{Sumber Bahan Hukum}

Berdasarkan atas penggunaan bahan hukum primer dan bahan hukum sekunder dalam penelitian hukum normatif, masing-masing dapat diuraikan sebagai berikut dibawah ini:

1. Bahan Hukum Primer.

Bahan hukum primer adalah bahan hukum yang mempunyai otoritas, yang terdiri dari peraturan perundang-undangan dan catatan-catatan resmi atau risalah dalam pembuatan suatu peraturan perundang-undangan serta putusan hakim. Bahan hukum primer yaitu bahan-bahan hukum yang sifatnya mengikat digunakan terutama berpusat pada perundang-undangan yang berlaku di Indonesia. ${ }^{13}$ Sebagai landasan utama yang dipakai dalam rangka Penulisan ini diantaranya adalah Undang-Undang Dasar Negara Republik Indonesia Tahun 1945, Kitab Undang-undang Hukum Perdata, UndangUndang Nomor 2 Tah8un 2014 tentang Perubahan Atas Undang-Undang Nomor 30 Tahun 2004 tentang Jabatan Notaris.;

2. Bahan Hukum Sekunder.

Bahan hukum sekunder merupakan bahan hukum yang memberikan penjelasan mengenai bahan hukum primer. Bahan hukum sekunder dalam penelitian ini terdiri dari Buku-buku hukum, jurnal-jurnal hukum, karya tulis hukum atau pandangan ahli hukum yang termuat dalam dalam media masa, kamus dan enslikopedi hukum (beberapa penulis hukum menggolongkan enslikopedi hukum kedalam bahan hukum tersier) dan Internet dengan menyebut nama dan situsnya.

\subsection{Teknik Pengumpulan Bahan Hukum}

Metode pengumpulan bahan hukum yang dipergunakan dalam penelitian ini adalah dengan menggunakan metode bola salju (snowball method). Adapun metode yang dimaksud dengan metode bola salju adalah menggelinding terus menerus sampai menemukan titik jenuh, dan hal ini mengacu kepada peraturan perundang-undangan dan buku-buku hukum dalam daftar pustaka. Pengumpulan bahan hukum primer, bahan hukum sekunder dan bahan hukum tersier di inventarisasi dan diklasifikasi secara sistematis sesuai dengan permasalahan yang dibahas dalam penelitian ini. ${ }^{14}$ Dengan pengklasifikasian diharapkan dapat memudahkan melakukan analisis terhadap permasalahan yang menjadi obyek penelitian dengan mengelaborasikan antara bahan hukum primer dan bahan hukum sekunder serta bahan hukum tersier yang dianalisis dan disusun secara sistematis.

${ }^{13}$ H. Zainuddin Ali, (2009), Metode Penelitian Hukum, Sinar Grafika, Jakarta, h.47

${ }^{14}$ I Made Wahyu Chandra Satriana, 2013, Kebijakan Formulasi Keadilan Restoratif Dalam Sistem Peradilan Pidana, (tesis) Program Studi Magister (S2) Ilmu Hukum Universitas Udayana, Denpasar, h.36 


\section{$2.4 \quad$ Teknik Analisis Data}

Teknik analisis bahan hukum dalam penelitian ini menggunakan teknik deskripsi, teknik interpretasi, dan teknik evaluasi. Teknik deskripsi adalah teknik dasar analisis yang tidak dapat dihindari penggunaanya. Deksripsi berarti uraian apa adanya terhadap suatu kondisi atau posisi dari proposisi-proposisi hukum atau non hukum. Teknik interpretasi berupa penggunaan jenis-jenis penafsiran dalam ilmu hukum seperti penafsiran gramatikal, historis, sistimatis, teleologis, kontekstual dan lain-lain. Teknik evaluasi adalah penilaian berupa tepat atau tidak tepat, setuju atau tidak setuju, benar atau salah, sah atau tidak sah oleh peneliti terhadap suatu pandangan, proposisi, pernyataan rumusan norma, keputusan baik yang tertera dalam bahan hukum primer maupun dalam bahan hukum sekunder.

\section{Hasil dan Pembahasan}

\subsection{Kewenangan Notaris Selaku Pejabat Pembuat Akta Tanah (PPAT) Dalam Kaitannya Dengan Pembayaran Pajak BPHTB Atas Jual Beli Tanah Dan Bangunan}

Menurut ketentuan pasal 15 ayat 1 Undang-Undang Jabatan Notaris yang menentukan bahwa:

Notaris berwenang membuat akta autentik mengenai semua perbuatan, perjanjian, dan ketetapan yang diharuskan oleh peraturan perundangundangan dan/atau yang dikehendaki untuk dinyatakan dalam akta autentik, menjamin kepastian tanggal pembuatan akta, menyimpan akta, memberikan grosse, salinan dankutipan akta, semuanya itu sepanjang pembuat akta itu tidak ditugaskan atau dikecualikan kepada pejabat lain atau orang lain yang ditetapkan oleh undang-undang.

Menurut Penjelasan UUJN bahwa Negara Indonesia adalah negara hukum yang menjamin adanya kepastian, ketertiban dan perlindungan hukum yang berintikan kebenaran dan keadilan. Dalam hukum nasional alat bukti yang utama adalah surat dan untuk menjamin adanya kepastian, ketertiban dan perlindungan hukum maka diperlukan alat bukti autentik supaya dapat menentukan dengan jelas hak dan kewajiban para pihak yang bersepakat.

Bagian umum penjelasan tersebut juga diuraikan bahwa akta autentik sebagai alat bukti yang terkuat dan sempurna. Dengan akta autentik maka memberikan kejelasan akan hak dan kewajiban para pihak. Keberadaan akta autentik akan terlihat manfaatnya jikalau ada permasalahan sengketa. Ketika terjadi sengketa maka akta yang dibuat oleh Notaris menjadi alat bukti yang terkuat sehingga tidak perlu alat bukti lain untuk menjelaskan bahwa akta perjanjian itu benar. Notaris/PPAT sebagai pejabat umum harus bertindak sesuai dengan aturan dan dengan prinsip kehatihatian sehingga klien yang akan menggunakan jasa Notaris agar diketahui terlebih dahulu identitas lengkapnya. ${ }^{15}$ Eksistensi dan wewenang seorang Notaris bersumber pada atribusi yang diberikan oleh undang-undang, sedangkan eksistensi dan wewenang PPAT tidak bersumber dari undang-undang melainkan diatur dalam PP 24

${ }^{15}$ Ida Bagus Paramaningrat Manuaba, (2017), Prinsip Kehati-Hatian Notaris Dalam Membuat Akta Autentik, Acta Comitas, Universitas Udayana, Bali 
Tahun 1997 tentang Pendaftaran tanah. ${ }^{16}$

Peraturan tentang jabatan PPAT di Indonesia telah diatur dalam Peraturan Pemerintah Nomor 37 Tahun 1998, pasal 1 angka 1 tentang pejabat umum yang diberi wewenang untuk membuat akta autentik mengenai perbuatantertentu. Pada umumnya PPAT adalah Notaris yang memiliki wewenang untuk membuat akta autentik namun selain Notaris pemerintah juga menunjuk bebrapa pejabat lain untuk menjadi PPAT sebagaimana diatur dalam, Pasal 1 angka 2 dan 3 Peraturan Pemerintah Nomor 37 Tahun 1998 tentang PPAT.

Pasal 1 angka (1) dinyatakan PPAT sementara adalah pejabat pemerintah yang ditunjuk karena jabatannya untuk melaksanakan tugas PPAT dengan membuat akta PPAT di daerah yang belum ada PPAT. PPAT sementara biasanya yaitu samata atau kepala desa tertentu untuk melaksanakan tugas PPAT. ${ }^{17}$

PPAT merupakan pejabat yang berwenang membuat akta untuk perjanjian yang bermaksud untuk melakukan pemindahan hak ats tanah, memberikan suatu hak baru atas tanah, menggadaikan tanah atau meminjam uang dengan hak atas tanah sebagai tanggungan. Adapun yang bisa diangkat menjadi PPAT adalah: ${ }^{18}$

1. Notaris

2. Pegawai-pegawai bekas pegawai dalam lingkungan direktorat jendral agraria yang dianggap mempunyai pengetahuan cukup.

3. Para pegawai pamong praja yang pernah melakukan tugas seorang PPAT.

4. Orang-orang lain yang telah lulus dalam ujian yang diadakan oleh direktorat jendral agrarian.

Peran PPAT dalam melindungi para pihak terhadap pelaksanaan jual beli tanah dan/atau bangunan adalah dengan melakukan pemeriksaan sertipikat (cek bersih) sebelum ditandatanganinya akta oleh para pihak. Secara materiil kewenangan pemeriksaan sertipikat hak atas tanah tersebut terletak pada Kantor Badan Pertanahan Nasional setempat, sedangkan PPAT hanya secara formil saja yakni melakukan pemeriksaan sertipikat ke Kantor Badan Pertanahan Nasional. Pada dasarnya pemeriksaan sertipikat tersebut telah bersih atau tidak, bukan merupakan hak dari PPAT tetapi melaikan hak dari BPN yang menentukan apakah sertipikat tersebut tidak terdapat silang sengketa maupun terikat suatu hak tanggungan pada bank.

Pentingnya pemeriksaan sertipikat hak atas tanah tersebut merupakan suatu hal yang diharuskan, supaya tidak terjadi hal-hal yang merugikan para pihak maupun pihak ketiga. Hal ini dilakukan untuk menjamin kepastian hukum terhadap keadaaan dari tanah yang akan diperjanjikan tersebut. Hal tersebut sangat penting untuk menghindari agar pihak yang akan mendapatkan hak berupa tanah dari obyek jual beli tanah tersebut tidak mendapatkan masalah atau kerugian dari tanah yang

${ }^{16}$ Linda Erma suryani, 2009, Kewenangan Notaris Dalam Membuta Akta Tanah Menurut UndangUndang Jabatan Notaris, Thesis Magister kenotariatan, Universitas Airlangga.

17 A.P. Parlindungan, Pendaftaran Tanah di Indonesia, CV. Mandar Madju, Bandung, 1999, h. 177

${ }^{18}$ Efendi Perangin, 1997, Hukum Agraria di Indonesia, Suatu Telaah dari sudut Pandang Praktisi Hukum, Ed.1 Cet. 4, PT. Raja Grafindo Persada, Jakarta, h. 3-4. 
dimilikinya tersebut. Kewenangan seorang Notaris dalam membuat akta yang berkaitan dengan pertanahan terbatas dibandingkan dengan kewenangan seorang PPAT dalam membuat akta pertanahan. Kewenangan Notaris dalam pertanahan terbatas tidak seperti PPAT. ${ }^{19}$

Sementara itu, berkenaan dengan cara pembuatan akta jual beli tanah dan/atau bangunan dikaitkan dengan ketentuan perpajakan, seorang PPAT tunduk pada ketentuan Pasal 24 ayat 1 Undang-Undang Nomor 20 Tahun 2000 Tentang BPHTB. Pemindahan hak atas tanah dan/atau bangunan ditandantangani apabila telah melunasi SSB, diserahkan kepada PPAT serta menyerahkan fotocopi SSB tersebut. Apabila SSB belum dibayarkan maka akta tidak dapat ditandatangani.

Menurut Herri Yudhianto Putro selaku Notaris/PPAT di Kabupaten Tabanan bahwa Notaris/PPAT tidak memiliki kewenangan untuk menerima penitipan pembayaran segala bentuk pajak apapun, namun dalam hal peran PPAT terhadap pembayaran pajak adalah memberitahukan kepada wajib pajak agar segera melakukan pembayaran pajak supaya akta jual belinya dapat dilakukan. Pembayaran Pajak tersebut sebenarnya memang kewajiban dari masing-masing wajib pajak tapi pada kenyataannya banyak para PPAT yang membantu melakukan pembayaran pajak. Seorang PPAT memang tidak berkewajiban untuk membayarkan pajak dan tidak dilarang pula untuk membantu melakukan pembayaran namun, untuk menjaga keprofesionalan dalam bekerja seorang Notaris seharusnya tidak melakukan tindakan yang diluar dari kewenangannya.

Kewenangan Notaris/PPAT selaku pejabat umum telah diatur secara tegas dalam UUJN dan Kode Etik. Setiap tindakan yang dilakukannya harus berdasar dan tidak bertentangan dengan peraturan yang ada. Tindakan dalam hal ini juga termasuk dalam tindakan-tindakan penitipan biaya-biaya pajak yang bukan merupakan kewenangannya. Seorang Notaris/PPAT harus bisa membedakan mana yang tindakannya berdasarkan diri sendiri dan mana yang tindakannya untuk dan atas nama jabatannya. ${ }^{20}$

Kaitan antara PPAT dengan pembayaran BPHTB bahwa PPAT sebagai pejabat yang mengesahkan transaksi pengalihan hak atas tanah dan/atau bangunan dimana terlebih dahulu agar dipenuhi syarat-syaratnya dalam pembayaran pajak-pajak. Menurut Herri Yudhianto Putro bahwa meskipun tidak diatur dalam kewenangan Notaris namun demi kelancaran dalam melaksanakan tugas profesi maka seorang PPAT muncul untuk memberikan informasi sekaligus sebagai "first gate" (gerbang pertama) dalam pengamanan penerimaan BPHTB sebelum melakukan Akta Jual Beli. Pada tahap ini PPAT harus dapat memberikan gambaran yang jelas tentang bentukbentuk pajak yang akan dikenakan kepada para pihak pada setiap transaksi peralihan hak atas tanah, pihak penjual dan pihak pembeli masing-masing mempunyai kewajiban dalam hal pembayaran pajak. Untuk Pihak penjual menanggung PPh yaitu

${ }^{19}$ Mohamad Adi Firmanu, 2010, Kewenagan Notaris Dalam Membuat Akta Yang Berkaitan Dengan Pertanahan. Jurnal Hukum, Universitas Airlangga.

${ }^{20}$ I Gusti Agung Dhenita Sari, 2017, Kewenangan Notaris Dan PPAT Dalam Proses Pemberian Hak Guna Bangunan Atas Tanah Hak Milik, Mahasiswa Magister Kenotarian Fakultas Hukum Universitas Udayana. 
sebagai konsekwensi dari penghasilan yang ia peroleh atas dasar pemindahan haknya sedangkan bagi pihak pembeli diwajibkan membayar BPHTB dari hak yang ia peroleh.

Namun dalam hal ini seorang klien juga harus berhati-hati dan menilai terlebih dahulu karakter dari seorang Notaris/PPAT tersebut. Sehingga kepercayaan yang diberikan klien kepada Notaris/PPAT dapat terlaksana dengan aman dan lancar tanpa adanya penipuan atau penggelapan terhadapat penitipan uang tersebut. ${ }^{21}$ Seorang PPAT mempunyai tanggung jawab yang besar selain memastikan para pihak untuk melakukan pembayaran pajak sebelum akta jual beli tersebut dilakukan, maka seorang PPAT harus juga melakukan pengecekan/pemeriksaan terhadap sertipikat hak atas tanah. Dasar hukum dari kewenangan PPAT dalam melakukan pemeriksaan sertipikat hak atas tanah telah dijelaskan sebelumnya bahwa seorang PPAT dalam melaksanakan tugasnya apabila adanya pengalihan hak atas tanah sebelum diadakan atau dilaksanakannya pengalihan hak atas tanah tersebut dibuat dalam akta otentik maka harus dilakukan pemeriksaan sertipikat hak atas tanah.

Kewenangan pemeriksaan sertipikat hak atas tanah pada Kantor Pertanahan setempat adalah didasarkan kepada kewenangan PPAT tersebut dalam pembuatan akta. Pentingnya pemeriksaan sertipikat hak atas tanah tersebut merupakan suatu hal yang diharuskan, hal ini demi mengetahui bahwa objek dari tanah tersebut bebas dari silang sengketa maupun tidak terikat hak tanggungan pada suatu bank.

Subjek dalam peralihan hak atas tanah dan bangunan adalah orang pribadi atau badan. Orang pribadi dan badan yang dimaksud di sini bisa berkedudukan sebagai pembeli. Bagi pembeli dikenai pajak atas perolehan hak atas tanah dan bangunanyang diterimanya yaitu BPHTB. Sedangkan objek pajak pembeli adalah perolehan hak atas tanah dan bangunan hal ini sesuai dengan Pasal 2 ayat 1 Undang-Undang Nomor 20 tahun 2000 tentang BPHTB

Tarif pajak BPHTB yang dikenakan terhadap orang pribadi/badan yang mengalihkan sebesar $5 \%$ (lima persen) dari jumlah bruto nilai pengalihan hak atas tanah dan bangunan yang dikurangkan terlebih dahulu dengan NPOPTKP. Tata cara pembayaran pajak atas BPHTB yaitu:

1. Mengisi SSB yang biasanya sudah tersedia di kantor PPAT dan biasanya dalam pengisian dibantu oleh para pegawai PPAT. Formulir SSB ini terdiri dari 6 (enam) rangkap

2. Setelah Surat Setoran BPHTB diisi oleh wajib pajak, maka wajib pajak membayar sendiri atau biasanya dalam melakukan pembayaran pajak BPHTB tersebut dapat juga dibantu oleh petugas PPAT ke tempat pembayaran yang ditunjuk. Hal ini disebabkan para klien biasanya ingin penyelesaiannya sekaligus dengan pembuatan akta. Mengenai tempat pembayaran biasanya dilakukan di Bank Persepsi, yaitu Bank Pemerintah yang ditunjuk oleh menteri keuangan untuk menerima pembayaran pajak dari wajib pajak.

\footnotetext{
${ }^{21}$ Sari Devi Nurmala (2017) Analisis Penerapan Sanksi Pidana Penggelapan Titipan Uang Pajak Bea Perolehan Hak atas Tanah Dan Bangunan (BPHTB) Yang Dilakukan Oleh Notaris-PPAT, Jurnal Mahasiswa, Universitas Sebelas Maret.
} 
Jadi pada dasarnya peran Notaris selaku PPAT dalam Pembayaran Pajak BPHTB saling berkaitan yang tidak dapat dipisahkan satu sama lain dalam hal peralihak hak atas tanah dan bangunan. Namun pada dasarnya peran Notaris/PPAT hanya sebatas memastikan pembayaran pajak telah dilakukan sehingga proses peralihan dapat dilakukan. Hal tersebut karena sebelum melakukan perbuatan hukum dalam akta Jual Beli di hadapan PPAT, pajak BPHTB tersebut harus telah lunas dibayar oleh wajib pajak, sehingga wajib pajak dapat memperlihatkan fotocopi pembayaran pajak tersebut sebagai bukti bahwa telah dilakukan pembayaran atas kedua pajak tersebut.

\subsection{Tanggung Jawab Notaris yang Menerima Penitipan Pembayaran BPHTB.}

Dalam kamus Besar Bahasa Indonesia tanggung jawab berarti menanggung segala sesuatu. Tanggungjawab merupakan kesadaran manusia akan tingkah laku perbuatan yang disengaja maupun yang tidak disengaja. Tanggungjawab juga berarti perbuatan sebagai suatu perwujudan akan kesadaran akan kewajibannya. Dengan demikian, tanggungjawab dapat diartikan kesadaran yang terdapat dalam diri seseorang yang mana setiap tindakannya akan mempunyai pengaruh bagi dirinya sendiri. Dalam bukunya Hans Kelsen membagi pertanggungjawaban menjadi empat macam yaitu:22

1. Pertanggungjawaban individu yaitu seorang individu bertanggung jawab terhadap pelanggaran yang dilakukannya sendiri.

2. Pertanggungjawaban kolektif, yaitu seseornag individu bertanggung jawab atas suatu pelanggaran yang dilakukan orang lain.

3. Pertanggungjawaban berdasarkan kesalahan yang berarti bahwa seorang individu betanggungjawab atas pelanggaran yang dilakukannya karena sengaja.

4. Pertanggungjawaban mutlak yang berarti bahwa seorang individu bertanggung jawab atas pelanggaran yang dilakukannya.

Notaris/PPAT merupakan profesi yang cukup beresiko karena harus memposisikan pelayana yang terbaik kepada masyarakat. Oleh karena ketaatan terhadap moral dan norma-norma hukum yang tunduk pada kode etik profesi, sehingga dapat memperkuat norma hukum positif yang telah ada. Notaris tidak boleh berpihak kepada salah satu pihak dan juga harus memiliki kecerdasan dan emosional yang stabil sehingga mampu meposisikan diri ketika berhadapan dengan klien.

Notaris harus menjunjung tingga profesinya sebagai pejabat umum yang mana dalam pelaksanaannya dengan cepat dan jujur namun sesuai dengan kode etik profesinya. Notaris akan bertanggung jawab kepada negara dan masyarakat artinya negara telah memberi kepercayaan untuk menjalankan sebagian tugas negara dan harus dilaksanakan sesuai dengan aturan yang telah ditentukan.

Seorang Notaris wajib bertanggung jawab kepada negara yang telah memberikan tugas untuk membuat alat bukti berupa akta yang mempunyai kekuatan pembuktian

${ }^{22}$ Hans Klesen, 2006, terjemahan Raisul Mutaqien, Teori Hukum Murni, Nuansa dan Nusamedia, Bandung, h.140 
yang sempurna. Selainitu Notaris juga mampu menformulasikan kehendak para pihak dalambentuk akta yang sesuai dengan peraturan perundang-undangan. ${ }^{23}$

Menurut Herri Yudhianto Putro bahwa seorang Notaris/PPAT dalam melaksanakan tugas harus bertanggung jawab penuh terhadap perbuatan hkum yang akan timbul dikemudian hari dan bahkan tanggungjawab moral sebagai professional. Apabila merugikan pihaklain, Notaris/PPAT harus dapat mempertanggungjawabkan semua pekerjaanya di depan hukum secara perdata maupun pidana. Begitu pula dalam hal penitipan pembayaran pajak, ketika terjadi permasalahan maka Notaris/PPAT ikut terlibat didalamnya.

Dalam pasal 1 angka 1 Undang-Undang BРНTB telah dirumuskan sebagai berikut: bea perolehan hak atas tanah dan bangunan adalah pajak yang dikenakan atas perolehan hak atas tanah dan bangunan yang selanjutnya disebut pajak. BPHTB merupakan salah satu bentuk pajak objektif atau pajak yang terutang dan harus dibayar oleh pihak yang melakukan transaksi atas tanah dan bangunan. Pengaturan pembayaran pajak BPHTB telah diatur dalam Undang-Undang dan yang mempunyai kewajiban untuk membayarnya yaitu wajib pajak yang bersangkutan. ${ }^{24}$

Subyek pajak merupakan orang atau badan namun dalam pajak ini orang/ badan yang memperoleh hak atas tanah dan bangunan. Hal ini telah diatur dalam pasal 4 UndangUndang Nomor 20 Tahun 2000 tentang BPHTB, yaitu:

1. Subyek pajak yaitu orang atau badan yang memperoleh hak atas tanah dan bangunan

2. Subjek pajak sebagaimana dimaksud pada ayat 1 yang dikenakan kewajiban bayar pajak menjadi wajib pajak menurut Undang-Undang ini.

Obyek pajak dalam Undang-Undang BPHTB yaitu:

1. Perolehan hak atas tanah dan bangunan karena pemindahan hak. yang mengakibatkan perolehan hak atas tanah dan bangunan yang merupakan obyek pajak BPHTB meliputi:

a) Perolehan hak karena jual beli,.

b) Perolehan hak karena tukar menukar.

c)Perolehan hak karena hibah

d) Perolehan hak karena hibah wasiat.

e)Perolehan karena waris.

f) Perolehan karena pemasukan dalam perseroan atau inbreng

g) Perolehan hak karena pemisahan hak yang mengakibatkan peralihan.

h) Perolehan hak karena pembeli dalam lelang

i) Perolehan hak sebagai pelaksanaan dari putusan hakim yang telah mempunyai kekuatan hukum tetap.

j) Perolehan hak karena penggabungan usaha.

k) Perolehan hak karena peleburan usaha.

1) Perolehan hak karena pemekaran usaha.

${ }^{23}$ Habib Adjie, 2015, Hukum Notaris Indonesia (Tafsir Tematik Terhadap UU Nomor 2 Tahun 2014 Tentang Perubahan atas Undang-Undang Nomor 30 Tahun 2004 Tentang Jabatan Notaris), PT Refika Aditama, Surabaya, h. 35.

${ }^{24}$ I Gusti Agung Putra Wiryawan, 2018, Pengaturan Tentang Pengenaan Pajak Bea Perolehan Hak atas Tanah Dan Bangunan (BPHTB) Atas Hibah Wasiat. Mahasiswa Magister Kenotariatan Fakultas Hukum Universitas Udayana Bali. Acta Comitas 
m) Perolehan hak karena adanya hibah.

2. Perolehan hak atas tanah dan bangunan karena pemberian hak baru. Pemberian hak baru yang mengakibatkan perolehan hak atas tanah dan bangunan yang merupakan obyek BPHTB yaitu:

a. Perolehanhak karena adanya pemberian hak baru sebagai kelanjutan pelepasan hak.

b. Perolehan hak karena pemberian hak baru diluar pelepasan hak yaitu pemberian hak baru dari negara kepada orang pribadi atau badan hukum menurut peraturan perundang-undangan yang berlaku.

Pembayaran pajak BPHTB merupakan kewajiban bagi wajib pajak untuk menyelesaikan transaksinya sesuai peraturan perundang-undangan. Kewajiban pembayaran BPHTB adalah kewajiban wajib pajak bukan kewajiban Notaris/PPAT. Notaris disini hanya membantu kliennya untuk menyetor kan pajaknya. Dalam hal in Notaris hanya membantu untuk memberi pelayanan terbaik bagi kliennya.

Undang-Undang BРHTB memberikan ketentuan yang harus diikuti oleh pejabat umum yang berwenang dalam peralihan hak atas tanah dan bangunan yaitu:

1. Notaris/PPAT hanya dapat menandatangani akta pemindahan hak atas tanah dan bangunan setelah WP menyerahkan bukti pembayaran pajak BPHTB.

2. Kepala Kantor Lelang hanya dapat menadatangani risalah lelang perolehan hak atas tanah dan banguna setelah WP menyerahkan bukti pembayaran BPHTB.

3. Pejabat yang berwenang menandatangani dan menerbitkan surat keputusan pemberian hak atas tanah dan bangunan setelah memberikan bukti setoran pembayaran BPHTB.

4. Terhadap pendaftaran peralihan hak atas tanah karna waris atau hibah wasiat hanya dapat dilakukan oleh pejabat pertanahan kabupatern/kota dengan menyerahkan bukti pembayaran pajak BPHTB.

Berdasarkan Pasal 24 ayat (1) mengatur bahwa kewajiban pembayaran pajak BPHTB merupakan kewajiban wajib pajak bukan Notaris/PPAT. Dalam pasal tersebut hanya menegaskan bahwa Notaris/PPAT bisa menandantangani akta apabila wajib pajak telah membayar pajak BPHTB. Oleh karena itu, Notaris disini hanya berperan untuk membantu klien untuk menyetorkan pajak BPHTB. Undang-Undang juga tidak ada mengatur bahwa kewenangan PPAT untuk mengetahui kebenaran pembayaran BPHTB dan yang berhak memeriksa adalah Dinas Pendapatan Daerah dengan melakukan verifikasi dengan mencocokkan Nomor Surat Setoran dengan data yang ada.

Dengan demikian Notaris/PPAT yang telah menerima penitipan pembayaran pajak BPHTB dari kliennya maka berdasarkan atas pasal 24 UU BPHTB bahwa yang menyetorkan BPHTB adalah wajib pajak bukan Notaris. Apabila Notaris telah menerima titipan tersebut maka Notaris harus segera menyetorkan uang tersebut dan jika tejadi permaslahan dalam hal pembayaran tersebut maka Notaris/PPAT ikut bertanggung jawab atas permasalahan yang terjadi. Oleh karena itu maka Notaris dalam menjalankan tugas dan jabatannya dalam memberi pelayanan kepada klien harus lebih berhati-hati dan tetap menjunjung UUJN dan kode etik profsesi sehingga dalam menjalankan jabatannya bisa dengan aman dan lancar. 


\section{Kesimpulan}

Berdasarkan pembahasan permasalahan yang telah diuraikan diatas, maka dapat disimpulkan bahwa dalam menjalankan jabatannya peran Notaris selaku PPAT terhadap pembayaran pajak adalah memberitahukan kepada wajib pajak agar segera melakukan pembayaran pajak supaya akta jual belinya dapat dilakukan, dan sebagai seorang Notaris/PPAT juga dapat membantu para klien untuk membayarkan pajaknya apabila para klien tidak mengetahui tata cara pembayaran pajak tersebut atau awam mengenai perpajakan. Pembayaran Pajak tersebut sebenarnya memang kewajiban dari masing-masing wajib pajak tapi pada kenyataannya para PPAT yang membantu melakukan pembayaran pajak tanpa ada pungutan lain dalam hal membantu pembayaran pajak itu, tetapi ada juga yang para wajib pajak yang hanya tidak bisa mengisi formulir pembayaran pajak tersebut, dan PPAT hanya membantu melakukan pengisian formulir tetapi pembayaran dilakukan oleh wajib pajak tersebut. Berdasarkan pasal 24 ayat 1 Undang-Undang BPHTB maka kewajiban pembayaran BPHTB adalah kewajiban wajib pajak dan bukan kewajiban Notaris/PPAT namun karena Notaris tersebut telah menerima penitipan pembayaran BPHTB dari kliennya maka Notaris tersebut harus sbertanggung jawab dalam jabatannya untuk menyetorkan pajak BPHTB tersebut walaupun dalam Undang-Undang BPHTB tidak ada diatur tentang kewajiban Notaris/PPAT untuk melakukan pembayaran pajak BPHTB atau penitipan pembayaran pajak BPHTB, penitipan ini dilakukan karena telah dipercaya oleh kliennya. Sehingga apabila terjadi keterlambatan atau tidak dibayarnya pajak BPHTB yang dititipkan wajib pajak kepada Notaris/PPAT maka Notaris bertanggung jawab berdasarkan jabatan dan personalnya karena terkait dengan fungsinya sebagai seorang Notaris selaku PPAT dalam memberikan pelayanan yang baik terhadap klien. Dengan demikian penulis menyarankan supaya kepada Pemerintah atau Ikatan Notaris Indonesia (INI) untuk membuat suatu aturan yang tegas terkait kewenangan Notaris dalam menerima segala bentuk titipan uang maupun barang, karena Notaris bukan merupakan Lembaga penitipan melainkan Pejabat Umum yang berwenang untuk membuat akta autentik, serta selalu untuk memberi sosialisasi terhadap klien yang kurang memahami tentang prosedur pembayaran pajak ataupun hal lain yang berkaitan dengan profesi Notaris.

\section{Daftar Pustaka}

Buku

Adjie, Habib (2015), Hukum Notaris Indonesia (Tafsir Tematik Terhadap UU Nomor 2 Tahun 2014 Tentang Perubahan atas Undang-Undang Nomor 30 Tahun 2004 Tentang Jabatan Notaris), PT Refika Aditama, Surabaya

Kansil C.S.T., dkk., (1996) Pokok-Pokok Etika Profesi Hukum, PT.Pradnya Paramita, Jakarta.

Kelsen Hans, Teori Hukum Murni dengan judul buku asli General Theori of Law and State, Alih Bahasa Somardi, Rimdi Press, Jakarta.

Parlindungan A.P., (1999) Pendaftaran Tanah di Indonesia, CV. Mandar Madju, Bandung,.

\section{Jurnal}

Andi Indah Rizky Y, 2017, Tanggungjawwab Notaris Selaku Pejabat Pembuat Akta Tanah Dalam Pemungutan Bea Perolehan Hak atas Tanah Dan Bangunan Di Kota Makassar, Jurnal Akta. 
Ida Bagus Paramaningrat Manuaba, (2017), Prinsip Kehati-Hatian Notaris Dalam Membuat Akta Autentik, Mahasiswa Magister Kenotariatan Fakultas Hukum Udayana. Acta Comitas.

I Gusti Agung Dhenita Sari, 2017, Kewenangan Notaris Dan PPAT Dalam Proses Pemberian Hak Guna Bangunan Atas Tanah Hak Milik, Mahasiswa Magister Kenotarian Fakultas Hukum Universitas Udayana. Acta Comitas.

I Gusti Agung Putra Wiryawan, 2018, Pengaturan Tentang Pengenaan Pajak Bea Perolehan Hak atas Tanah Dan Bangunan (Bphtb) Atas Hibah Wasiat. Mahasiswa Magister Kenotariatan Fakultas Hukum Universitas Udayana. Acta Comitas.

Sari, Devi Nurmala (2017) Analisis Penerapan Sanksi Pidana Penggelapan Titipan Uang Pajak Bea Perolehan Hak Atas Tanah Dan Bangunan (BPHTB) Yang Dilakukan Oleh Notaris-PPAT, Jurnal Mahasiswa, Universitas Sebelas Maret.

Prayojana, D. A., Murni, R. R., \& Dharmawan, N. K. S. (2018). Pelaksanaan Penyelesaian Pelanggaran Kode Etik Notaris Tentang Pemasangan Papan Nama Notaris Di Kota Denpasar. Acta Comitas, 213-218.

Sinuhaji, Z. B. Y. (2015). Persekutuan Perdata Menurut Undang-Undang Nomor 2 Tahun 2014 Tentang Perubahan Atas Undang-Undang Nomor 30 Tahun 2004 Tentang Jabatan Notaris Dan Kitab Undang-Undang Hukum Perdata Terhadap Prinsip Kemandirian Notaris. Kumpulan Jurnal Mahasiswa Fakultas Hukum.

Yuniati, S. (2017). Mekanisme Pemberian Sanksi Terhadap Notaris Yang Melakukan Pelanggaran Kode Etik Jabatan Notaris. Jurnal Akta.

Zakhina, I. (2016). Karakteristik Dan Bentuk Persekutuan Perdata Notaris. Kumpulan Jurnal Mahasiswa Fakultas Hukum.

Santosa, K dan Hanim, L. (2017). Perlindungan Hukum Bagi Pihak-Pihak Yang beritikad Baik Dalam Pembatalan Perjanjian Jual Beli Tanah dan Bangunan, Jurnal Akta, 4(2), 150-155.

\section{Peraturan Perundang-undangan}

Undang-Undang Dasar Republik Indonesia Tahun 1945.

Undang-Undang Nomor 20 Tahun 2000 tentang Bea Perolehan Hak Atas Tanah dan Bangunan.

Undang-Undang Nomor 2 Tahun 2014 atas perubahan Undang-Undang 30 Tahun 2004 tentang Jabatan Notaris.

Peraturan Pemerintah Nomor 37 Tahun 1998 tentang Pejabat Pembuat Akta Tanah. 